not in a position to recover their capital by selling the underlying assets as the ownership of the assets has remained with the originators.

The difference between asset-based and asset backed șukuk is important, as significant implications follow for investors' protection at a time of distress. The investment of the holders of asset-backed șukuk is protected against loss, as they are the legal owners of the assets. Should a default occur, they can recover their capital investment by selling the assets in the open market. They can do this because they are the legal owners of those assets. Holders of asset-based șukuk , by contrast, cannot sell the underlying assets to recover their investment, as they are merely the 'beneficial' but not the legal owners of the assets. Thus, holders of asset-based $s u k \bar{u} k$ are exposed to the risk that they might lose their investment. From a legal point of view, the status of the holders of asset-based șukuk is no different from that of unsecured creditors.

In Chapter 16 ("How Expansive Are the Frontiers") Rodney Wilson discusses some "unresolved issues" (p. 335). However, while we find optimism about "where the industry is going", a number of pressing issues receive little or no attention. One of these is investor (sukūk buyer) protection. Another is the question of whether șukuk should continue replicating conventional bonds or be structured as genuine PLS instruments.

In general, the book raises more questions than it answers. Let us hope the next volume will rectify these shortcomings.

\title{
Bertrand de Speville, Overcoming Corruption: The Essentials
}

(Kuala Lumpur: Research for Social Advancement, 2010), 112 pp.

ISBN: 978-967-5942-03-7

\section{Zarina Nalla International Institute of Advanced Islamic Studies (IAIS) Malaysia}

The title of the book is very reflective of its length and style: brief and succinct almost like a handbook, it is meant for anticorruption decision-makers from the developed and developing world who are too busy to read laborious pieces on the subject.

The author, an English law barrister who went to Hong Kong in 1981, became Solicitor General prior to his appointment as Commissioner of the Independent Commission Against Corruption (ICAC) of Hong Kong from 1992 to 1996, just before the city was returned to China. He turned ICAC into a leading anti-graft body admired by international observers. In London, where he is currently based, he became adviser to the Council of Europe's Multidisciplinary Group on Corruption from 1997 to 2003. He is consulted by a number of international development 
institutions. De Speville's many years of experience in the anti-graft industry provide him with a solid foundation for writing a book such as this. Overcoming Corruption, which was launched in Malaysia recently, has also been translated into several European languages, Arabic, and even Pashto.

The author begins with an overview of the 'basics' of corruption before highlighting the seven essentials of fighting graft and concludes with a list of possible pitfalls which can arise in this unenviable occupation. The key elements of the blue print, in no particular order, include: political will, values in criminal, administrative and civil law, a national strategy, coordinated action, resources, public support and endurance. In each chapter, de Speville explains every one of the seven prerequisites. His descriptions appear so simple and straightforward, as if to make up for the arduous and thorny road ahead for corruption fighters.

The strategy for fighting corruption comprises three steps: "enforcement of the laws against corruption; second, prevention of corruption by minimizing in systems and procedures, the opportunities for corrupt activity; third, the education of the community about corruption and the development of public support for the fight." Coordinating those three steps is indeed a challenge but is key to the success of the grand plan. In fact, the coordinating role is so vital that de Speville recommends that a person or body is asked to be committed to this task alone.

He also repeatedly emphasizes the powerful function of the public. People need to be first convinced that the investigation carried out by an anti-corruption agency is credible. If inquiries are not known to be conducted properly, allegations will continue to accumulate and poison the atmosphere. Confidence will then plummet and before long all public figures are perceived to be 'corrupt'. This state of mind is pervasive in many countries where people are unsure of the work of anti-graft bodies.

At the book launch, this particular point was supported by Chief Commissioner Datuk Abu Kassim Mohamed, head of the Malaysian Anti-Corruption Commission (MACC), who has recently begun the process of involving credible and well-known citizens in the work of the commission. A committee of such individuals will decide if investigations have been carried out successfully in a particular case and have the mandate to close the case or continue the investigation. Work in Hong Kong, Singapore and Botswana has revealed that most investigations do not result in prosecution. This is because of the absence of the necessary evidence or a mistaken allegation.

Additionally, de Speville explains that many nations underestimate how critical it is to educate the public about corrupt practices, core values, and prevention. Countries can utilise the mass media and also direct face to face communication to convey the important message. He realises that the most effective channel is through community leaders who are well-placed to speak to their members or congregations on the importance of the issue at hand. 
Interestingly, the author highlights the conceptual difference between good governance and anticorruption work. He states that they "are not at all the same thing," because the former is concerned with operations but the latter is really about preserving certain values that the community holds dear. He warns that governments who fail to make the distinction continue making reforms that are doomed to fail as they are repeatedly undermined by pre-existing corrupt practices. Moreover, the core values on corruption should be clearly stated in the criminal law of any modern state, he points out. Often laws against corruption are inadequate because they are unintelligible and convoluted.

The main prerequisites of any anticorruption agency are accountability and independence. Proven best practices show that the leadership of such an organisation should be of ministerial or permanent secretary rank to be effective when dealing with all three elements of the strategy identified earlier. This position should be occupied by a candidate selected by the head of the state after consulting the leader of the opposition.

De Speville prescribes six lines of accountability which would ensure that an agency is answerable for its conduct - to the executive, the legislature, the public prosecutor, the courts, the advisory committees, and directly to the public via the media. The agency should be required to only deal with criminalities that are directly connected to or facilitated by corruption. Dealing with offences outside its control will only undermine the raison d'être of an agency created specially to address a particular type of crime.

Experience has confirmed that a nation's past has the potent ability to destroy anticorruption efforts or policies. This for mainly two reasons: first, those with vested interests will use their influence to ensure that the war against corruption does not take off; secondly, as the flood gate opens to years of corruption, the volume of cases may overwhelm officers and discourage them from continuing with their mission. The only salvation would be for the leadership of the country to decide at the outset, how to deal with what has already taken place. Much political will is required to manage corrupt and powerful individuals and also to decide when and how to successfully accommodate past misconducts. There are moral, practical, and political justifications to consider for such a course.

Charting and walking down the road out of corruption is a painful process, but it is comforting to know that "it will be more than compensated for when the results begin to show, when the country's revenue streams begin to flow again into the treasury, when citizens begin to realise that things can be different, that the cost of corruption does not have to be part of the cost of living or doing business."

Measuring progress is best done by way of public opinion surveys done independently of the anticorruption body which should examine: the public 
opinion of the situation in the country, the public perception of the local anti-graft organisation, and the community's individual attitude towards corrupt practices.

It would have been ideal, if the author could have drawn upon his own immense practical experiences and highlighted some key case studies - without revealing actual names. Real cases leave a lasting trail.

Finally, de Speville has dedicated his book to "To all those who long for freedom from corruption," and this clearly includes every member of every society who cares for their nation. Therefore, this simple book deserves our full attention.

\section{Response to Daniel Martin Varisco: Review of Christoph Marcinkowski (transl., intro.): Measures and Weights in the Islamic World. An English Translation of Professor Walther Hinz's Handbook 'Islamische Maße und Gewichte', with a foreword by Professor Clifford Edmund Bosworth, FBA}

(Kuala Lumpur: ISTAC 2003), xxii, 98 pp. ISBN 983-9379-27-5.

In: Journal of the American Oriental Society 125, no. 2 (2005), 333-5.

\section{Christoph Marcinkowski International Institute of Advanced Islamic Studies (IAIS) Malaysia}

Since its publication, Measures and Weights in the Islamic World has established itself as a standard work - at least in the English-speaking Muslim world.

There can be no doubt that reviews, when done out of purely professional interest, might be considered a valuable tool for raising scholarly standards. The reviewer is not personally known to me as we are apparently working in different fields - Varisco (Hofstra University, Hempstead NY, United States) seems to be largely involved in anthropology, with emphasis on Yemen, whereas I have so far contributed toward the study of contemporary and historical Shi' ism as well as security issues and Iranian Studies. However, the overall tenor of the wording of Varisco's review as well as what he deigned to present to his audience as 'facts' do require a stern response $^{1}$ in order to re-establish a climate of mutual respect and fairness among colleagues. For matters of brevity, I should like to focus in the following on only some selected issues:

(i) his criticism of the purpose and usefulness of the work under review;

(ii) matters of translation;

(iii) some basic advice on collegiality and fairness.

To begin with (i), Varisco (pp. 333-4) doubted the purpose of my translation of a work that had been published in German by the late Professor Walther Hinz several 